\title{
The Structure of the European Commission as Enforcer of Competition Law
}

The history of competition policy is closely linked to the history of the EU. The Treaty of Paris of $195^{1}$ establishing the European Coal and Steel Community (ECSC) dealt in Article 65 with agreements and concerted practices between firms and associations of firms which tend directly or indirectly to prevent, restrict or distort normal competition within the Common Market. Article 66 of the same treaty dealt with mergers and Article 67 with the abuse of dominant positions. These articles of the ECSC Treaty became the blueprint for the competition law provisions that were adopted in the treaties establishing the European Communities and the European Union.

The Treaty of Paris entrusted the High Authority with all issues concerning the enforcement of competition policy, a task that the Treaty of Rome later placed in the hands of the European Commission.

The first implementing regulation was adopted after the entry into force of the Treaty Establishing the European Economic Community (EEC). Regulation 17/1962 established the European Commission's mandate and investigative powers for the enforcement of Articles 85 and 86 of the Treaty (now Articles 101 and 102 TFEU). ${ }^{1}$ This regulation remained in force from 1962 until 2002 when it was replaced by Regulation 1/2003 (Regulation on Procedure) with the purpose of meeting the challenges of an integrated market and a future enlargement. ${ }^{2}$

When the Commission acts as the enforcer of EU competition law, it combines investigative, prosecutorial and adjudicative functions. What is more, the adjudicative functions that the Commission performs are split, as shown in Figure 5 above, between DG COMP, which prepares decisions, and the College of Commissioners, which adopts the decisions. Therefore, the current analysis follows the European Commission first as a political institution, and second as a bureaucracy (Chapter 9). I then focus on enforcement procedure and the Commission's powers of investigation in the field of competition law

1 Regulation No 17 First Regulation Implementing Articles 85 and 86 of the Treaty, OJ P o13, 21.2.1962, pp. 204-211.

2 Council Regulation (EC) No 1/2003 of 16 December 2002 on the implementation of the rules on competition laid down in Articles 81 and 82 of the Treaty, OJ L oo1, 04.01.2003, pp. 1-25. 
(Chapters 10 and 11). Lastly, I highlight the due process elements present in the procedure and propose a framework for assessing the Commission's independence (Chapters 12, 13 and 14).

\subsection{The European Commission as a Political Institution}

The European Commission is described as the "core executive" of the European Union. ${ }^{3}$ It is seen by some as displaying many of the characteristics of national governments. ${ }^{4}$ However, as Curtin rightly noted, the European Commission is not only in the business of service delivery, but has also outstanding policymaking and regulation tasks, as well as limited enforcement tasks in the fields mandated by the Treaties. ${ }^{5}$

Article 17(1) TEU states that the European Commission

shall promote the general interest of the Union and take appropriate initiatives to that end. It shall ensure the application of the Treaties, and of the measures adopted by the institutions pursuant to them. It shall oversee the application of Union law under the control of the Court of Justice of the European Union. It shall execute the budget and manage programs. It shall exercise coordinating, executive and management functions, as laid down in the Treaties. With the exception of the common foreign and security policy, and other cases provided for in the Treaties, it shall ensure the Union's external representation. It shall initiate the Union's annual and multiannual programming with a view to achieving interinstitutional agreements.

The European Commission has been the subject of a series of reforms in the last fifteen years, the most important of which led to the politicisation of the Commission's leadership. The politicisation of the Commission is an important phenomenon to take into account when assessing its independence. Three factors contributed to the politicisation of the Commission's leadership: (1) changing recruitment patterns; (2) changing role conceptions and (3) altering the interaction pattern between the Commissioners and the senior officials

3 Hix, S. The Political System of the European Union. Basingstoke: Palgrave Macmillan, 2005 , p. 32.

4 Egeberg, M. “The European Commission." European Union Politics. Ed. M. Cini. Oxford: Oxford University Press, 2003, pp. 131-147.

5 Curtin, op. cit., p. 91. 
of the Commission. ${ }^{6}$ This shift leaned toward controlling the influence that the Commission exerts over the design and execution of the policy making process. The motivation for this shift was "that the Commission's services were perceived as too powerful, and too unresponsive to political direction, and unable to ensure efficient performance". ${ }^{7}$

The Commissioners appointed nowadays tend to have serious political careers behind them, having had very often lead roles in, or even headed, ministries or large domestic agencies. In addition, the procedure for the appointment of the Commissioners has been politicised as well, since the European Parliament continues to play an increased role in the selection process. Lastly, the background of the Commissioners has changed towards a generalist education as opposed to the more specialized training of the senior officials. Wille concludes that "generalist political executives will be less able to contest issues on substantive grounds than executives with more specialized training".

Another issue related to the Commission's independence is the posterior careers embraced by the Commissioners. Wille, in her insightful study of the subject, has noted that the politicisation of the Commission has led to a change of heart concerning the Commissioners' involvement with domestic politics. In the past, Commissioners were expected to remain above domestic politics while pursuing their European mandates in order to ensure independence in decision-making. However, this

requirement has slowly been eroded as the institution has become more politicised. Commissioners no longer cut themselves off from national politics when they move to Brussels. Politics, at both national and international level, are important for political professionals, as they provide access to the accumulated resources for a career following their stint in the EU Commission. ${ }^{9}$

In this sense, Wille shows that Prodi and Monti became Prime Ministers of Italy, Grybauskaite became president of Lithuania and Lamy was appointed Director-General of the wTo.

6 Wille, Anchrit. "Senior Officials in a Reforming European Commission: Transforming the Top?" Management Reforms in International Organizations. Eds. M.W. Bauer and C. Knill. Baden-Baden: Nomos, 2007, pp. 37-5o.

7 Wille (2007), op. cit., p. 34.

8 Wille (2007), op. cit., p. 18.

9 Wille, Anchrit. The Normalization of the European Commission: Politics and Bureaucracy in the EU Executive. Oxford: Oxford University Press, 2013, p. 76. 
Lastly, ex-commissioners also move to business and commercial positions after leaving the Commission by joining lobbying groups or think-tanks. Eleven out of the fifteen outgoing commissioners of the first Barroso Commission were recruited for corporate positions within six months of leaving that commission. ${ }^{10}$

\subsubsection{Cumulating Constitutional Functions}

The European Commission cumulates three constitutional powers in the field of competition law enforcement: legislative power, executive power and judicial power. These functions can be shared with other EU institutions, or exercised individually by the Commission only.

The European Commission participates in the development of EU competition law by submitting proposals for legislative action to the Council and to the European Parliament. Most often, the Commission shares the legislative power with the Council of Ministers - the main legislative body of the union and with the European Parliament. Other bodies that are involved with competition law-making are the Advisory Committee, which attends hearings and makes comments on the Commission's proposed decisions or legislation in the field of antitrust, and the Economic and Social Committee, which has an advisory role with regard to competition policy.

The Commission can also act as unique legislator when it adopts implementing regulations, the most recent of which is Commission Regulation $773 / 2004$ that is binding in its entirety and directly applicable in all member states. ${ }^{11}$

Another instance in which the Commission acts as unique legislator in the field of competition law is when it adopts the so-called block exemption regulations, which are used to declare certain categories of state aid compatible with the TFEU. If certain categories of state aid fall under the ambit of the block exemption regulation, they are exempted from the otherwise regular duty of prior notification and Commission approval. Thus, the block exemption regulation concerning de minimis aid exempts aid amounts up to 200,000 euro per undertaking over a three-year period because they are deemed to have no impact on competition and trade in the internal market. ${ }^{12}$ Measures that fulfil

\footnotetext{
$10 \quad$ Wille (2013), op. cit., p. 77 .

11 Commission Regulation (EC) No 773/2004 of 7 April 2004 relating to the conduct of proceedings by the Commission pursuant to Articles 81 and 82 of the EC Treaty, OJ L 123, 27.4.2004, pp. 18-24.

12 Commission Regulation (EU) No 1407/2013 of 18 December 2013 on the application of Articles 107 and 108 of the Treaty on the Functioning of the European Union to de minimis aid, oJ L 352, 24.12.2013, pp. 1-8.
} 
the criteria of the regulation do not constitute state aid according to the meaning of EU rules and therefore do not need to be notified to the Commission for approval before they are implemented. The General Block Exemption Regulation (GBER) has considerably extended the scope of exemptions from prior notification of state aid granted to companies. ${ }^{13}$ Under the revised GBER, member states are able to grant more aid in higher amounts without having to notify them to the Commission for prior authorisation, because they are less likely to lead to undue distortions of competition.

In addition to implementing Council regulations and adopting its own regulations pursuant to powers delegated by the Council, the Commission can adopt non-legislative measures such as notices and guidelines, also called soft law. Although the legal status of these instruments is open to debate, what is certain is that they provide important information and clarification on the Commission's practice and can trigger legitimate expectations. The Commission's notice on immunity from fines (hereafter, Leniency Notice) clarified the information an applicant needs to provide to the Commission to benefit from immunity and introduced a procedure to protect corporate statements made by companies. ${ }^{14}$ The Guidelines concerning the Method of Setting Fines provided that companies may be fined up to $10 \%$ of their total annual turnover. ${ }^{15}$ Within this limit, the guidelines provided that fines may be based on up to $30 \%$ of the company's annual sales to which the infringement relates, multiplied by the number of years of participation in the infringement. Moreover, a part of the fine - the so-called "entry fee" - may be imposed irrespective of the duration of the infringement.

The European Commission is the main executive body of the EU ensuring that the provisions of the TFEU, the regulations, the directives and the decisions are implemented in accordance with the principles of EU law. In the field of competition law, Article 105 TFEU provides that the Commission shall ensure the application of Articles 101 and 102 TFEU, shall investigate any infringements and shall bring to an end those that are incompatible with the internal market.

\footnotetext{
13 Commission Regulation (EU) 651/2014 of 17 June 2014 declaring certain categories of aid compatible with the internal market in application of Articles 107 and 108 of the Treaty, oJ L 187, 26.6.2014, pp. 1-78.

14 Commission notice on immunity from fines and reduction of fines in cartel cases, oJ C 298, 8.12.2006, pp. 17-22.

15 Guidelines of method of setting fines imposed pursuant to Article 23(2)(a) of Regulation No 1/2003, OJ C 210, 1.9.2006, pp. 2-5.
} 
Until 1st of May 2004, the Commission was composed of twenty members: two for each of the larger member states - Germany, France, the UK, Italy and Spain - and one for each of the smaller member states - Austria, Belgium, Denmark, Finland, Greece, Ireland, Luxembourg, the Netherlands, Portugal and Sweden. The waves of accession have, however, changed the Commission's structure and the College of Commissioners - the body ensuring the Commission's political leadership - is now composed of 28 Commissioners, one from each EU country. The Commissioners are elected for a term of five years and each Commissioner is entrusted with a specific policy area by the President of the Commission.

The Commission is also responsible for international cooperation in competition matters. For this purpose, the Commission cooperates on a regular basis with competition authorities from the countries with whom the EU has concluded agreements concerning cooperation in competition matters: the United States, Canada, Japan, South Korea and, more recently, Switzerland. The Commission also works with the ICN, the OECD, the UNCTAD and the WTO.

The Commission has a parallel competence with the NCA s and the national courts to enforce competition law whenever a breach of Article 101 or Article 102 TFEU has taken place. As Van Bael has noted, "in addition to its pivotal role in the allocation of cases, the Commission retains some further control over the proceedings taking place before NCA s and national courts". ${ }^{6}$

During enforcement procedures of Articles 101 and 102 TFEU, the Commission exercises judicial functions: the Commission decides which cases to investigate from those that are notified and which cases not to pursue, which investigative measures to use, which facts to support with evidence, which questions to ask about the relevant undertakings and what measures to employ to end the damaging behaviour.

Cases that end with a formal decision can be challenged before the GC, exercising jurisdiction at the first instance in actions brought against the Commission pursuant to Article 263 TFEU (action for annulment), Article 232 (failure to act) and Article 229 TFEU (review of penalties imposed by the Commission).

The decisions of the GC can be challenged before the CJEU that became a court of appeal insofar as competition decisions of the Commission are concerned. In addition, the Court of Justice has jurisdiction, pursuant to Article 267 $\mathrm{TFEU}$, to give preliminary rulings at the request of domestic courts concerning 
the interpretation or the validity of community law provisions, including in the field of competition law.

\subsubsection{The Reform and Independence of the Commissioners}

The Treaty attaches particular importance to the independence of the Commission and prescribes both substantive and procedural standards of independence. Substantively, Article 17(3) TFEU requires that the members of the Commission be selected from persons whose independence is beyond doubt. Procedurally, the Treaty provides that in carrying out its responsibilities, the Commission shall be independent. In addition, the members of the Commission shall neither seek nor take instructions from any government or other institution, body, office or entity. They shall also refrain from any action incompatible with their duties or the performance of their tasks. Lastly, Article 245(1) TFEU requires the member states to respect the Commission's independence and to refrain from influencing them in the performance of their tasks.

The TFEU empowers the President of the Commission to request the resignation of a Member of the Commission. ${ }^{17}$ Also, Members of the Commission no longer fulfilling the conditions required for the performance of their duties or guilty of serious misconduct may be compulsorily retired or deprived of pension rights or other benefits. ${ }^{18}$

Important developments concerning the notion of independence have been introduced by the Code of Conduct for the Commissioners. The 1999 Code of Conduct for Commissioners, adopted after the resignation of the Santer Commission, developed the obligations of independence and integrity imposed upon the members of the community by the treaties. Following several studies concerning the effectiveness of codes of conduct for the holders of public office worldwide and within the European Union, President Barroso announced his intention to review the Code of Conduct for Commissioners. ${ }^{19}$

The 2011 Code of Conduct for Commissioners strengthened the notion of independence by establishing clearer rules on political activities, on the activities

\footnotetext{
17 Article 17(6) of the Treaty on the Functioniong of the European Union.

18 Articles 245 and 247 of the Treaty on the Functioniong of the European Union.

19 Demmke, Christoph, Mark Bovens, Thomas Henökl and Timo Moilanen. Regulating Conflicts of Interest for Holders of Public Office in the European Union. Luxembourg: Office for Official Publications of the European Communities, 2008.

European Parliament. Directorate General For Internal Policies. The Code of Conduct for Commissioners - improving effectiveness and efficiency: Study. 2009. Available at http://www.europarl.europa.eu/document/activities/cont/200907/20090728ATT59122/ 20090728ATT59122EN.pdf accessed on 23 February 2021.
} 
performed by the commissioners after leaving the Commission and by establishing a procedure for dealing with the conflicts of interest. ${ }^{20}$

The 2018 Code of Conduct for Commissioners replaced the previous one and has been adopted with the view of integrating the experience gained in its application and in order to be "up to the high ethical standards that are expected of the Members of the Commission". ${ }^{21}$

The 2018 Code of Conduct for Commissioners stresses the fact that the Members of the Commission have political responsibility and are collectively accountable to the European Parliament. In view of this, the code stresses that "members shall behave and perform their duties with complete independence, integrity, dignity, with loyalty and discretion" and "shall observe the highest standards of ethical conduct". ${ }^{22}$ Also, interestingly, the code stipulates that members shall not act or express themselves "in a manner which adversely affects the public perception of their independence, their integrity or the dignity of their office" and shall avoid any situation which may give rise to a conflict of interest or which may "reasonably be perceived as such".23 (emphasis added) In case of a conflict of interest, members must recuse themselves from any decision or instruction of the file and from the participation in any discussion, debate or vote in relation to the matter creating a conflict of interest. ${ }^{24}$

The code provides for the establishment of the Independent Ethical Committee in order to assist the Commission in the application of the Code of Conduct. ${ }^{25}$

\subsection{The European Commission as an Autonomous Bureaucracy}

The TFEU does not contain any provisions concerning the functioning of the European Commission as a bureaucracy. This is surprising, taking into account the size and the importance of this administration. The Commission accounts

20 European Commission. Code of Conduct for Commissioners. C(2011) 2904 final. 20 Apr 2011. Available at https://ec.europa.eu/info/sites/info/files/code-of-conduct-forcommissioners_april2o11_en.pdf accessed on 23 February 2021.

21 European Commission. Commission Decision of 31.1.2018 on a Code of Conduct for the Members of the European Commission. C(2018) 700 final, p. 2. Available at https:// ec.europa.eu/info/sites/info/files/code-of-conduct-for-commissioners-2018_en_o.pdf accessed on 23 February 2021.

22 European Commission. C(2018) 700 final, quoted above, Article 2.

23 European Commission. $\mathrm{C}(2018) 700$ final, quoted above.

24 European Commission. C(2018) 700 final, quoted above, Article 4.

25 European Commission. C(2018) 700 final, quoted above, Article 12. 
for $46.6 \%$ of the total EU budget for administration and has more than 32 ,ooo posts of public servants. ${ }^{26}$

\subsubsection{The Autonomy of the European Commission}

Carpenter defines autonomy as the capacity of a bureaucracy to "take sustained patterns of action consistent with its own wishes, patterns that will not be checked or reversed by elected authorities, organized interests, or courts". ${ }^{27}$

The literature on the autonomy of bureaucracies focuses on how power is gained, distributed and redistributed in a state. Weber's model of ideal bureaucracy is an apolitical organization separated from the realm of politics. Even so, Weber recognized the "pure interest of the bureaucracy in power" and its "pure power instinct". ${ }^{28}$ Ideal bureaucrats who limit themselves to administering policies put in place by politicians are rare, though. Most commonly, they are thought to be playing the power game alongside politicians. This tension between elected and appointed, representative and administrative institutions leads to the "distinctive puzzle of the contemporary state, reflecting as it does the clash between the dual and conflicting imperatives of technical effectiveness and democratic responsiveness". 29

The political-bureaucratic interface of the Commission has been a subject of research, concern and debate. Günter Verheugen - a politician himself - presented in harsh terms the problematic relationship between the political and the administrative heads of the Commission. He has criticized Commission bureaucrats for the "permanent power struggle between the commissioners and their high-ranking bureaucrats", highlighting that "the whole development in the last ten years has brought the civil servants such power that in the meantime the most important political task of the 25 commissioners is controlling this apparatus". ${ }^{30}$

26 European Commission. European Commission Key HR Figures 2019, available at: https:// ec.europa.eu/info/about-european-commission/organisational-structure/commissionstaff_en accessed on 23 February 2021.

27 Carpenter, D. The Forging of Bureaucratic Autonomy: Reputations, Networks, and Policy Innovations in Executive Agencies, 1862-1928. Princeton: Princeton University Press, 2001, p. 14.

28 Weber, Max. "On Bureaucracy." From Max Weber: Essays in Sociology. Eds. Hans Gerth and C. Wright Mills. New York: Oxford University Press, 1946, p. 233.

29 Aberbach, J., R. Putnam and B. Rockman. Bureaucrats and Politicians in Western Democracies. Cambridge: Harvard University Press, 1981, p. 3.

$30 \quad$ Manhony, Honor. "Commission bureaucrats are getting too powerful, says Verheugen." $E U$ Observer. 5 Oct 2006. Available at https://euobserver.com/political/22572 accessed on 23 February 2021. 
Although surprising, the affirmation of Günter Verheugen, was not signalling a novel phenomenon. The relationship between politicians and civil servants is one of the most complicated relationships of many governance systems because while each has their role in running the public sector, "it is often assumed that both have their own goals, interests, resources and commitments". 31

As a seminal study on the autonomy of the European Commission has shown, "even though the Commission is in many ways a typical Weberian bureaucracy, it is also a unique administration with features that set it apart from the most national and international public bureaucracies". ${ }^{22}$ The autonomy of the European Commission stems from the following sources: (1) Formal authority granted by law; (2) Legitimacy derived from a combination of technical expertise and functional monopoly and (3) Organizational culture. ${ }^{33}$ The authors argue that the waves of transformation that have affected the Commission have not diminished its autonomy. On the contrary, they have contributed to the Commission's increased autonomy vis-á-vis its political masters.

\subsubsection{The Reform and Independence of the EU Commission's Civil Service}

Curtin describes three categories of civil servants working in the Commission: (1) core Eurocrats - civil servants located predominantly in the Commission, working either in the Policy Directorates General or in the General Secretariat; (2) seconded national experts - national civil servants involved in EU policymaking and funded by the national governments; and (3) national civil servants and scientific experts - civil servants with technical backgrounds. ${ }^{34}$

The perception of the European civil service has rarely been positive. In fact, the perception of "Eurocrats" has been that they "had too much power, that they were poor managers, and that their recruitment was mainly the result of patronage". ${ }^{35}$ Therefore, the 2001 Kinnock reforms described in Section 2.2. above, radically reformed the Commission's management. However, these reforms resulted in other, unforeseen consequences.

31 Wille, Anchrit. "Bridging the Gap: Political and Administrative Leadership in a Reinvented Commission." Institutional Dynamics and the Transformation of Executive Politics in Europe. Ed. M. Egeberg. Mannheim: ConNEx Report Series 3, 2007, pp. 7-41.

$3^{2}$ Ellinas and Suleiman, op. cit., p. 196.

33 Ellinas and Suleiman, op. cit., pp. 18-35.

34 Curtin, op. cit., pp. 106-113.

35 Wille (2013), op. cit., p. 121. 
Wille has criticised the de-professionalisation and, instead, "managerialisation" of the upper echelons of the Commission's civil service, as a result of which "policy-oriented professionalism is replaced by managerial skills, performance measurement and financial control. The focus for most senior officials is shifted from a professional policy advisory role with a clear focus on content to a role of process management". 36

While the recruitment of senior civil servants in the Commission has been removed from the influence of the member states, political capital and previous experience working for a commissioner played an important role in securing a position as a Director-General. ${ }^{37}$ Georgakakis showed that "the administrators of Europe tend to be involved in a long-term process of construction of European social positions, closely linked to European institutions, while those who embody their authority - Commissioners - are less and less involved". ${ }^{38}$

EU legislation contains significant provisions seeking to ensure that the members of the European civil service will act independently and impartially. Article 11 of the EU Staff Regulations provides that "an official shall carry out his duties and conduct himself solely with the interests of the Union in mind. He shall neither seek nor take instructions from any government, authority, organisation or person outside his institution. He shall carry out the duties assigned to him objectively, impartially and in keeping with his duty of loyalty to the Union". 39

Before recruiting an official for an EU institution, the appointing authority must examine if the candidate has "any personal interest such as to impair his independence or any other conflict of interest". ${ }^{40}$ Furthermore, "an official may neither keep nor acquire, directly or indirectly, in undertakings which are subject to the authority of the institution to which he belongs or which have dealings with that institution, any interest of such kind or magnitude as might impair his independence in the performance of his duties". ${ }^{41}$

Lastly, the Code of Good Administrative Behaviour for Staff of the European Commission in their Relations with the Public also calls for the staff "to be courteous, objective and impartial". This code also asks that "staff shall always act

\footnotetext{
36 Wille (2007), op. cit., p. 23.

37 Georgakakis, Didier. "Tensions within Eurocracy?" European Consortium of Political Research. Aug 2009, Potsdam, Germany.

38 Georgakakis, op. cit., p. 30.

39 Regulation No 31 (EEC), 11 (EAEC), laying down the Staff Regulations of Officials and the Conditions of Employment of Other Servants of the European Economic Community and the European Atomic Energy Community. oJ P 045, 14.6.1962, p. 1385.

40 Regulation No 31 (EEC), quoted above, article 11.

41 Regulation No 31 (EEC), quoted above, article 11.
} 
objectively and impartially, in the Community interest and for the public good. They shall act independently within the framework of the policy fixed by the Commission and their conduct shall never be guided by personal or national interest or political pressure". 42

\subsubsection{The Directorate-General for Competition}

"It is clear that the actual physical task of carrying out an organization's objectives falls to the persons at the lowest level of the administrative hierarchy. The automobile, as a physical object, is built not by the engineer or the executive, but by the mechanic on the assembly line. The fire is extinguished, not by the fire chief or the captain, but by the team of firemen who play a hose on the blaze".

HERBERT. A. SIMON

The Commission is organised into thirty-three departments known as Directorates-General (DG s) and eleven services. Every DG is specialised in one area. The department specialized in the area of competition law is DG COMP, which comprises nine sector-based directorates:

Directorate A: Policy and Strategy

1) Antitrust Case Support and Policy

2) Mergers Case Support and Policy

3) State Aid Strategy

4) European Competition Network

5) International Relations

6) Private Enforcement

Directorate B - Markets and Cases I: Energy and Environment

1) Antitrust: Energy, Environment

2) State Aid I

3) State Aid II

4) Mergers

Directorate C - Markets and Cases II: Information, Communication and Media

1) Antitrust: Telecoms

2) Antitrust: Media

42 European Commission. Code of Good Administrative Behaviour: Relations with the Public. OJ L 267, 20.10.200o. 

3) Antitrust: IT, Internet and Consumer Electronics
4) State Aid
5) Mergers
6) Antitrust: E-commerce and data economy

Directorate D - Markets and Cases III: Financial Services
1) Antitrust: Payment Services
2) Antitrust: Financial Services
3) Task Force Financial Crisis
4) State Aid: Financial institutions I
5) State Aid: Financial institutions II
6) State Aid: Financial institutions III
7) Mergers

Directorate E - Markets and Cases Iv: Basic Industries, Manufacturing and Agriculture

1) Antitrust: Pharma and Health Services

2) Antitrust: Consumer Goods, Basic Industries, Agriculture and Manufacturing

3) State Aid: Industrial Restructuring

4) Mergers

5) Task Force Food

Directorate F - Markets and Cases v: Transport, Post and Other Services

1) Antitrust: Transport, Post and Other Services

2) State Aid: Transport

3) State Aid: Post and Other Services

4) Mergers

Directorate G - Cartels
1) Cartels I
2) Cartels II
3) Cartels III
4) Cartels IV
5) Cartels v

Directorate H - State Aids: General Scrutiny and Enforcement
1) Infrastructure and Regional Aid
2) R\&D\&I, IPCEI and environment
3) Fiscal Aid
4) Enforcement and Monitoring
5) Tax Planning Practices

Directorate R - Horizontal Management

1) Registry and Transparency 
2) Finance and Internal Compliance

3) Information Technology 43

DG COMP had - as of 31.12.2018 - 799 staff members, including managers, case-handlers and assistants. ${ }^{44}$ DG COMP is led by a Director-General, who is assisted by three Deputy Director-Generals, one Chief Economist and one Principal Adviser. There are also two hearing officers who report directly to the Competition Commissioner. The mission of the hearing officers is to ensure due process, to safeguard the parties' procedural rights and to contribute to the quality of the decision-making. DG COMP stated in 2014 that its staff was committed to "adhere to the highest standards of professionalism, intellectual rigour and integrity so as to ensure the highest standards in the enforcement of competition law". ${ }^{45}$

The DG COMP highlighted that its mission was to

enable the Commission to enhance consumer welfare in the EU and efficiently functioning markets by protecting competition and promoting a competition culture. This is done through the enforcement of competition rules and through actions aimed at ensuring that regulation takes competition duly into account among other public policy interests. ${ }^{46}$

DG COMP publishes Annual Reports on Competition Policy, Annual Management Plans and Annual Activity Reports that provide extensive yearly information on the work accomplished and the challenges encountered. DG СомP regularly evaluates its policies and samples of its case work. These evaluations represent

constructive-critical, evidence-based judgement of how well an EU measure (for instance legislation or soft law) adopted a few years ago has achieved its stated objectives, by looking at positive and negative aspects

43 European Commission. Directorate-General for Competition. Organigramme of $D G$ сомР. Available at http://ec.europa.eu/dgs/competition/directory/organi_en.pdf accessed on 23 February 2021.

44 European Commission. Directorate-General for Competition. 2018 Annual Activity Report. Ares(2019)3820496 - 14/o6/2019, p. 62. Available at https://ec.europa.eu/info/sites/info/ files/comp_aar_2018_final.pdf accessed on 23 February 2021.

45 European Commission. Directorate-General for Competition. Management Plan 2014, p. 14. Available at http://ec.europa.eu/competition/publications/annual_management_ plan/amp_2014_en.pdf accessed on 23 February 2021.

46 European Commission. Directorate-General for Competition. Management Plan 2014, quoted above, p. 4 . 
and intended and unintended impacts. It goes beyond a description of what has happened and analyses why and how certain impacts occurred. It helps the Commission to learn lessons from the past and improve its policies and interventions in the future. ${ }^{47}$

Most evaluations will focus on the relevance, effectiveness, efficiency, EUadded value and coherence of the legislation or of the adopted measures.

The DG COMP officials also offer training courses upon request to government officials, especially in relation to newly-adopted legislation.

The European Commission became more image-aware over time and invested resources in building and maintaining the image of a European administration that is approachable, communicative and responsive. This is particularly true about the DG COMP that - due to the nature of its work - is in constant dialogue with the business and the legal communities in Europe.

In 2010, DG COMP commissioned a Eurobarometer Stakeholder Report in order to obtain feedback on perceptions of the quality of its activities from its most important professional stakeholders: law firms, economic consultancies, business associations, companies, national competition authorities and EU Member State governments. A separate report was produced for each group and a final, aggregate report, was published in July 2010. The study covered all of the DG COMP's enforcement, policy and advocacy activities, and feedback was sought in particular in relation to the soundness of its legal and economic analyses, its transparency and procedural fairness, its economic effectiveness, and finally, its communication and international advocacy.

The DG COMP argued that it would use the findings of the study to achieve "more targeted and dynamic communication and interaction with its professional stakeholders and with the general public" in order to detect "areas of possible improvement in its cooperation and interrelations with stakeholders" and prioritise "its projects to achieve a greater impact on the markets".48 Finally the findings would serve to measure "its performance in a number of fields related to the quality and impact of its work". 49

47 European Commission. Directorate-General for Competition. Evaluation. Available at http://ec.europa.eu/dgs/competition/evaluation_en.htm accessed on 23 February 2021.

48 European Commission. Directorate-General for Competition. DG Competition Stakeholder Study: Aggregate Report. July 2010, p. 4. Available at http://ec.europa.eu/competition/ publications/reports/aggregate_report_en.pdf accessed on 23 February 2021.

49 European Commission. Directorate-General for Competition. DG Competition Stakeholder Study: Aggregate Report. July 2010, p. 4. 
The study enhances the Commission's image as a flexible, self-critical, communicative administration. In addition, its findings are interesting and beg closer analysis.

As a general rule, NCAs were the least critical of the DG COMP's activities; they often used words of praise for the Commission's work in the field of competition law. Member state governments, however, often expressed more reserved views and offered suggestions concerning possible ways of improving the directorate's work. The most critical stakeholders were, however, the law firms, economic consultancies, business associations and companies. These offered unique insights into their relationship with the DG COMP.

In the field of soundness of legal and economic analysis, the law firms praised the expertise of DG COMP's case handlers. However, a majority of respondents noted that the clarity of the legal analysis varied according to the area of competition policy involved. In cartels, for example, the legal analysis can be flawed by the Directorate's exclusive reliance on the information provided by leniency applicants. ${ }^{50}$

Predictability was perceived as a strong point in the Commission's work in the field of competition, with the exception of cartel decisions that seemed to be very difficult to predict. ${ }^{51}$ Other exceptions included instances where DG COMP changed its views mid-case, thus raising suspicions about political influence. ${ }^{52}$

Predictability of fines was perceived as a strong point, but some stakeholders expressed the view that the current level of fines had increased uncertainty for companies and this, in turn, had a negative impact on their accounts, share value, image and relationships with creditors. ${ }^{53}$

The legal community welcomed the increased involvement of economists in competition cases, however they also indicated that this impacts the length of the case and the data requests placed on the companies. ${ }^{54}$

$5^{\circ} \quad$ European Commission. Directorate-General for Competition. DG Competition Stakeholder Study: Stakeholder Report: Lawyers. August 2010, p. 7. Available at http://ec.europa.eu/ competition/publications/reports/lawyers_en.pdf accessed on 23 February 2021.

51 European Commission. Directorate-General for Competition. DG Competition Stakeholder Study: Stakeholder Report: Lawyers, quoted above, p. 10.

$5^{2}$ European Commission. Directorate-General for Competition. DG Competition Stakeholder Study: Stakeholder Report: Lawyers, quoted above, p. 9.

53 European Commission. Directorate-General for Competition. DG Competition Stakeholder Study: Stakeholder Report: Lawyers, quoted above, p. 12.

54 European Commission. Directorate-General for Competition. DG Competition Stakeholder Study: Stakeholder Report: Lawyers, quoted above, p. 13. 
One of the most criticised aspects of the Commission's work was its market understanding. Law firms complained that the Directorate's rotation policy, an over-academic outlook and lack of business experience affect its understanding of the market. One respondent argued that "even more important than their lack of business experience is their lack of business understanding; how commercial developments take place, how contracts work. That makes them over-suspicious. More practical experience would help". ${ }^{55} \mathrm{~A}$ few respondents argued that a way for DG COMP to improve its market and business understanding is a better communication with other DG s that possess in-depth knowledge about their respective fields. ${ }^{56}$

The DG COMP has also been criticised for the lack of transparency in its way of handling information before the adoption of the decisions, in particular requests for information that were sent out with extremely short deadlines or before holidays. ${ }^{57}$ Respondents praised the Commission's practice of consulting the public on new proposed legislation. However, they also noted that, despite wide public participation, the Commission almost never took into account the views expressed during this process.

An interesting part of the report refers to the DG COMP's respect of procedural rules. Although the respondents were merely invited to state their views on the observance of procedural rules by the Commission, they offered extensive input on the content of these rules as well. The respondents argued that the Commission complies with the existing rules, but that the rules themselves are "flawed and unfair". In particular, the fact that no independent, external authority was involved in the decision-making process and in the establishment of fines undermined the fairness of the procedure. ${ }^{58}$

The role of the hearing officer came under fire in particular, with one respondent stating that "the hearing officer made sure that the coffee is served at the right time and that the interpreters aren't too tired. They have no real role".59

The respondents argued that the burden on business had increased in recent years with the DG COMP asking more questions. They noted that no

55 European Commission. Directorate-General for Competition. DG Competition Stakeholder Study: Stakeholder Report: Lawyers, quoted above, p. 16.

56 European Commission. Directorate-General for Competition. DG Competition Stakeholder Study: Stakeholder Report: Lawyers, quoted above, p. 18.

57 European Commission. Directorate-General for Competition. DG Competition Stakeholder Study: Stakeholder Report: Lawyers, quoted above, p. 22.

58 European Commission. Directorate-General for Competition. DG Competition Stakeholder Study: Stakeholder Report: Lawyers, quoted above, p. 23.

59 European Commission. Directorate-General for Competition. DG Competition Stakeholder Study: Stakeholder Report: Lawyers, quoted above, p. 23. 
rules concerning the number and content of the questions existed and that the directorate's case handlers made large use of this instrument. As one respondent put it, "No official ever got sacked for asking questions". ${ }^{0}$ They referred to the pharmaceutical sector inquiry during which questionnaires were sent out every Friday for six months and 200 people worked for five months to meet the DG COMP's request for information. ${ }^{61}$

In the field of economic effectiveness of the Commission's detection policy, the respondents criticised the over-reliance on leniency programmes and stated that the large fines were beginning to have some negative or counterproductive effects. ${ }^{62}$

The speed of decision-making was the most criticised aspect of the DG COMP's work, especially in the field of cartels where timing is of particular importance: "Some cartel cases take forever, creating huge commercial uncertainty for the companies concerned. That uncertainty, dragging on for five or six years, is a real problem". ${ }^{63}$ The legal community also noted that their rights of defence "kick in" only after the DG COMP issues a statement of objections. Between the start of the case and the statement of objections though, the companies benefit from no procedural rights but have to answer all the Commission's questions. ${ }^{64}$

Another qualitative study was requested by DG COMP to focus on the perceived quality of the DG's enforcement work (antitrust and cartel, merger and state aid control) and policy and advocacy activities. ${ }^{65}$ The new study targeted the "DG Competition's professional stakeholders who are knowledgeable about its work, either by concrete involvement in case work as part of DG Competition's enforcement activities or indirectly, by having influenced or benefited from policy work".66

6o European Commission. Directorate-General for Competition. DG Competition Stakeholder Study: Stakeholder Report: Lawyers, quoted above, p. 25.

61 European Commission. Directorate-General for Competition. DG Competition Stakeholder Study: Stakeholder Report: Lawyers, quoted above, p. 25.

62 European Commission. Directorate-General for Competition. DG Competition Stakeholder Study: Stakeholder Report: Lawyers, quoted above, p. зо.

63 European Commission. Directorate-General for Competition. DG Competition Stakeholder Study: Stakeholder Report: Lawyers, quoted above, p. 3 o.

64 European Commission. Directorate-General for Competition. DG Competition Stakeholder Study: Stakeholder Report: Lawyers, quoted above, p. 3 .

65 European Commission. Directorate-General for Competition. DG Competition Stakeholder Survey: Aggregate Report. December 2014. Available at http://ec.europa.eu/competition/ publications/reports/survey2014/aggregate_report_en.pdf accessed on 23 February 2021.

66 European Commission. Directorate-General for Competition. $D G$ Competition Stakeholder Survey: Aggregate Report, quoted above, p. 5 . 
On the subject of soundness of legal and economic arguments, some lawyers noted that the quality of decision-making was dependent on the members of the case team and on the personality of the Commissioner. Thus,

prior to Neelie Kroes, Commissioners were considered by several participants to act more as administrators and they favoured sound decisions that took a long time to be produced. Neelie Kroes and Joaquin Almunia were seen by the same participants as politicians who regard competition law as a means of government and consequently put pressure on their staff to deliver faster decisions. ${ }^{67}$

In the same vein, some companies noted that where political motivations and influences were evident, the soundness of legal arguments tended to be less clear. Some companies also noted that the Commission occasionally seemed to decide the case up front and build legal argument opportunistically. ${ }^{68}$

The DG COMP's economic analyses were graded highly by the stakeholders and regarded as comprehensive, detailed, and data-driven and therefore trusted. ${ }^{69}$ However, critiques were expressed in relation to staff turnover and its impact on market knowledge. Also, some participants proposed the appointment of an independent Chief Economist, outside the Commission, to provide a more objective view. ${ }^{70}$

Unlike other topics discussed with the stakeholders which generated harmonized or clearly polarized views, highly varied views were expressed regarding the transparency of the DG COMP's work at different stages of the process and in different types of cases. ${ }^{71}$ Interestingly, transparency was also associated with the independence of data/information and judgement. The DG COMP was perceived as comparing and evaluating its own data which led to final decisions lacking independence. One participant noted that the

67 European Commission. Directorate-General for Competition. DG Competition Stakeholder Survey: Aggregate Report, quoted above, p. 12.

68 European Commission. Directorate-General for Competition. DG Competition Stakeholder Survey: Aggregate Report, quoted above, p. 13.

69 European Commission. Directorate-General for Competition. DG Competition Stakeholder Survey: Aggregate Report, quoted above, p. 19 .

70 European Commission. Directorate-General for Competition. DG Competition Stakeholder Survey: Aggregate Report, quoted above, p. 20.

71 European Commission. Directorate-General for Competition. DG Competition Stakeholder Survey: Aggregate Report, quoted above, p. 22. 
DG Competition does not handle the materials they are receiving (like documentation and expert opinions) independently since at the same time they also produce their own material which supports their own views and there is not an independent party included like there usually is in the US [or other countries] - in the court of law there is always a court which evaluates independently the opinions of both participants and after that reaches its verdict. ${ }^{72}$

Observance of procedural rules and of fairness standards were criticized more than other aspects of the DG COMP's work. Stakeholders noted that, although hearings were an opportunity to present a case, very little was seen to change as a result. Also, the fact that oral hearings were held late in the process meant that their impact on the outcome of the procedure was fairly limited. ${ }^{73}$ Although the hearing officer acted independently from the DG COMP during oral hearings, some stakeholders noted that in cartel cases, the process was not satisfactory, as they perceived the DG COMP to be acting simultaneously as "judge, jury and prosecutor". ${ }^{4}$ In addition, certain participants suggested that there should be an independent decision-maker for cartel cases. ${ }^{75}$

Some participants were concerned about the reactive nature of detection policy which resulted from DG COMP relying heavily on complaints and its leniency policy. ${ }^{76}$ In addition, investigations to detect infringements were perceived as inefficient, because they were too thorough in proportion to the suspected offence. ${ }^{77}$

Some business associations, companies, lawyers and economic consultancies suggested that sometimes political pressure influences the DG COMP in choosing which cases to pursue. They argued that "politicians, business lobbies or competitors (including other countries) with disruptive intentions can all exercise such pressure. For example, one lawyer mentioned that DG

72 European Commission. Directorate-General for Competition. DG Competition Stakeholder Survey: Aggregate Report, quoted above, p. 23.

73 European Commission. Directorate-General for Competition. DG Competition Stakeholder Survey: Aggregate Report, quoted above, p. 29.

74 European Commission. Directorate-General for Competition. DG Competition Stakeholder Survey: Aggregate Report, quoted above, p. 3 .

75 European Commission. Directorate-General for Competition. DG Competition Stakeholder Survey: Aggregate Report, quoted above, p. 25.

76 European Commission. Directorate-General for Competition. DG Competition Stakeholder Survey: Aggregate Report, quoted above, p. 34 .

77 European Commission. Directorate-General for Competition. $D G$ Competition Stakeholder Survey: Aggregate Report, quoted above, p. 35 . 
Competition focuses on the pharmaceutical sector because of political the influence, which has as purpose reducing the price of medicines.". 78

Settlement and commitment procedures were generally considered effective, but a few concerns were raised in relation to them. First, participants feared that the use of these procedures would lead to a lack of case-law and, consequently, a lack of clarity. Second, settlement and commitment procedures could be used by market actors in abusive ways and should be employed by the DG COMP judiciously. Lastly, these procedures may become arbitrary through their lack of precision and insight into how the DG COMP reasons. ${ }^{79}$

78 European Commission. Directorate-General for Competition. DG Competition Stakeholder Survey: Aggregate Report, quoted above, p. 40.

79 European Commission. Directorate-General for Competition. DG Competition Stakeholder Survey: Aggregate Report, quoted above, pp. 44-45. 